\title{
Industry 4.0 Implementation Barriers in Small and Medium Sized Enterprises: A Focus Group Study
}

\author{
G. Orzes ${ }^{1}$, E. Rauch ${ }^{1}$, S. Bednar ${ }^{2}$, R. Poklemba ${ }^{2}$ \\ ${ }^{1}$ Faculty of Science and Technology, Free University of Bozen-Bolzano, Bolzano, Italy \\ ${ }^{2}$ Faculty of Manufacturing Technologies, Technical University of Kosice, Kosice, Slovakia \\ (erwin.rauch@unibz.it)
}

\begin{abstract}
The attention devoted to Industry 4.0 by scholars, managers and policy makers has grown exponentially in the last few years. The goal of this paper is to empirically investigate the main barriers and difficulties faced by small and medium sized enterprises in Industry 4.0 implementation. We perform a systematic literature review on the topic and conduct some focus group studies in four countries (USA, Italy, Austria, and Thailand). We identify a set of barriers and obstacles and classified them into six categories: economic-financial, cultural, competencies/ resources, technical, legal, and implementation process. The results of the study have significant implications for both scientific research and management practice.
\end{abstract}

Keywords - Industry 4.0, implementation, roadmap, barriers, strategy, small and medium sized enterprises.

\section{INTRODUCTION}

Industry 4.0 refers to the "confluence of technologies ranging from a variety of digital technologies to new materials to new processes" [1]. The attention devoted to the topic by scholars, managers and policy makers has grown exponentially in the last few years $[2,3]$.

Despite the focus of most of the eight priority areas for action outlined in the final report of the Industry 4.0 working group (e.g., work organization and design, training and continuing professional development, resource productivity and efficiency; [4]) and the potential of Industry 4.0 to revolutionize management theory and practices [5], extant literature has mainly studied Industry 4.0 from a technological point of view [3]. Consequently, a detailed analysis of the implementation strategies, the main barriers faced, as well as on the impact on firms' operations and supply chains, is missing [5].

Our paper aims at starting to address the aforementioned gap by empirically investigating the main barriers and difficulties faced by SMEs in Industry 4.0 implementation. We focus on SMEs for two main reasons: (1) they are very important for many countries as a backbone of national economy; (2) on one hand they are expected to face more difficulties to adopt Industry 4.0 than large companies due to lacking resources and knowledge; on the other hand, they can more quickly change towards Industry 4.0 if a suitable roadmap is available.

\section{LITERATURE REVIEW}

We systematically reviewed the literature on obstacles and barriers in the implementation of Industry 4.0 technologies. We performed a keyword search in the most important electronic database (Elsevier's Scopus) using a combination of two set of keywords: (a) Industry 4.0-related terms (e.g. Industry 4.0, Industrial Internet, Fourth Industrial Revolution, $4^{\circ}$ Industrial Revolution, Internet of Things, Smart Manufacturing, Cyber-Physical Production Systems); and (b) barrier-related terms (Barrier*, Obstacle*, Challenge*, Problem*, SME*, Small and Medium Enterprise*). Through the abovementioned search strategy, we found 6,029 papers, which were then filtered using filter criteria and afterwards screened based on (i) title and (ii) abstract and then by (iii) full text. We excluded at this stage all papers that do not provide insights on the obstacles and barriers in Industry 4.0 implementation and which were written in other languages than English and German (we included as inclusion criteria also papers in German as Industry 4.0 concept was initially conceptualized in this country). The final sample consisted of 17 papers [6-22]. In addition, we added to the identified works also the following 3 studies from World Economic Forum [23], Deloitte [24] and IBM [25] found in the database Google Scholar as they address relevant content for our study. We then coded these papers based on the obstacles/barriers highlighted by each of them. The results of the systematic literature review are summarized in Table 1.

The reviewed papers highlight a set of 19 obstacles/barriers in Industry 4.0 implementation that were classified into 6 categories:

1. economic/financial (high investments required, lack of monetary resources, lack of clearly defined economic benefits);

2. cultural (lack of support by top management; preferred autonomy);

3. competencies/resources (lack of skilled employees, lack of technical knowledge; complexity of the Industry 4.0 application both technical and practical, need to find suitable research partner);

4. legal (data security concerns);

5. technical (lack of standards, uncertainty about the reliability of the systems, weak IT infrastructure, difficult interoperability/compatibility, technology immaturity);

6. implementation process (need for new business models, lack of methodical approach for implementation, high coordination effort). 
TABLE I

LITERATURE REVIEW $(\mathrm{E}=$ empirical, $\mathrm{C}=$ conceptual $)$

\begin{tabular}{|c|c|c|c|c|c|c|c|c|c|c|c|c|c|c|c|c|c|c|c|c|c|}
\hline & & 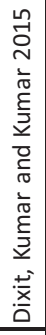 & 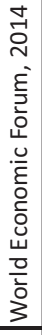 & 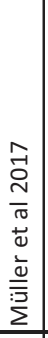 & 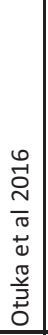 & 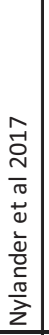 & 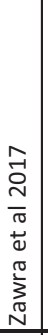 & 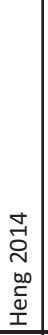 & 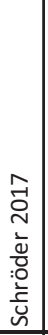 & 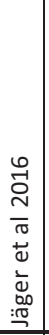 & 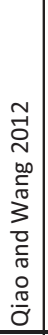 & 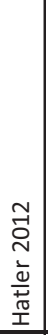 & 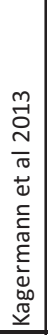 & 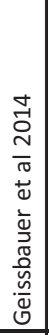 & 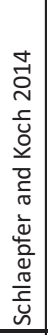 & 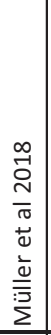 & 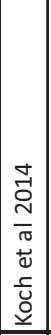 & 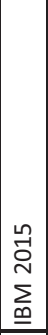 & 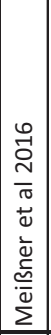 & 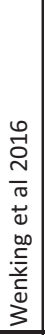 & 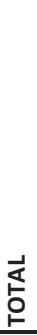 \\
\hline & Focus on SMEs & & & $x$ & $\mathbf{x}$ & $x$ & & $\mathrm{x}$ & $\mathbf{x}$ & $\mathbf{x}$ & & & & & & $\mathbf{x}$ & & & $\mathrm{x}$ & & 8 \\
\hline \multirow{3}{*}{$\begin{array}{l}\text { Economic } \\
\text { /Financial }\end{array}$} & High investements required & & & & & & & & & E & c & E & & $\mathrm{E}$ & & $\mathrm{E}$ & $\mathrm{E}$ & E & & C & 8 \\
\hline & Lack of monetary ressources & & & $\mathrm{E}$ & & & & & C & & & & & & & & & $\mathrm{E}$ & & C & 4 \\
\hline & Lack of clearly defined economic benefit & & E & & & & & & & & & & & E & & & $\mathrm{E}$ & & & & 3 \\
\hline \multirow{2}{*}{ Cultural } & Lack of support by top management & & $\mathrm{E}$ & & & & & & & & & & & $\mathrm{E}$ & & & E & $\mathrm{E}$ & & C & 5 \\
\hline & Preferred autonomy & & & $\mathrm{E}$ & & & & & & & & & & & & & & & & & 1 \\
\hline \multirow{4}{*}{$\begin{array}{l}\text { Competencies } \\
\text { /Resources }\end{array}$} & Lack of skilled employees & & $\mathrm{E}$ & & & & & & & $\mathrm{E}$ & & & & & $\mathrm{E}$ & & $\mathrm{E}$ & & $\mathrm{E}$ & c & 6 \\
\hline & Lack of technical knowledge & & & E & & c & & & c & & & E & $\mathrm{E}$ & E & & E & & E & E & c & 10 \\
\hline & Complexity & & & & & & & & & & & E & & & & & & E & & & 2 \\
\hline & Need to find suitable research partner & & & $\mathrm{E}$ & & & & & & & & & & & & & & & $\mathrm{E}$ & & 2 \\
\hline Legal & Data security concerns & c & E & & $\mathrm{E}$ & & & & c & $\mathrm{E}$ & & $\mathrm{E}$ & C & & $\mathrm{E}$ & $\mathrm{E}$ & $\mathrm{E}$ & $\mathrm{E}$ & & c & 12 \\
\hline \multirow{6}{*}{ Technical } & Lack of standards & c & E & & $\mathrm{E}$ & & c & c & c & & c & E & c & $\mathrm{E}$ & & & E & & $\mathrm{E}$ & c & 13 \\
\hline & Uncertainity about the reliability of the systems & & & & $\mathrm{E}$ & & & & & & & E & & & & & & & & & 2 \\
\hline & Weak IT infrastructure & & E & & $\mathrm{E}$ & & & & & $\mathrm{E}$ & & & & & $\mathrm{E}$ & & & $\mathrm{E}$ & E & C & 7 \\
\hline & Storage Data & C & & & & & C & & & & & & & & & & $\mathrm{E}$ & & & & 3 \\
\hline & Difficult Interoperability/Compatibility & & & & E & & C & C & & & & & & & & & & & & & 3 \\
\hline & Technology immaturity & & E & & & & & & & & & & & E & & & $\mathrm{E}$ & & & & 3 \\
\hline \multirow{3}{*}{$\begin{array}{l}\text { Implementation } \\
\text { process }\end{array}$} & Need for new business models & & E & E & & C & & & & $\mathrm{E}$ & & & & & & & & & & & 4 \\
\hline & Lack of methodical approach for implementation & & & & & & & & C & & & & & E & & & & & E & & 3 \\
\hline & High coordination effort & & & E & & & & & & & & & & & & & & & & & 1 \\
\hline
\end{tabular}

The literature is however characterized by some significant limitations. First, most papers (58\%) are published in conference proceedings or reports, therefore lacking a rigorous peer-review process. Second, only $42 \%$ of the studies are focused on small and medium enterprises. These companies have instead significant peculiarities, which call for a specific investigation. Finally, if we compare the list of barriers highlighted in Industry 4.0 literature (see Table 1) with the broader set of barriers in innovation adoption highlighted by the innovation management literature (see [26] and [27] among other), we noticed that various significant barriers are missing in Industry 4.0 literature. The comprehensiveness of the list of barriers to Industry 4.0 identified by extant literature is therefore called into question.

\section{METHODOLOGY}

Considering the novelty of the topic and the need for an in-depth exploration [28], we adopted the focus group methodology. This method was developed and extensively adopted in medical and marketing research; it is now accepted and established even in social science research [29].

Four focus groups (lasting one full working day) were organized in USA, Italy, Austria, and Thailand within the EU research project 'SME 4.0'. Each focus group was attended by 13-25 CEOs or technical managers of 7-10 SMEs belonging to different manufacturing sectors, including electronics, industrial and agricultural equipment, furniture, and metal carpentry (see Table 2). The composition of the SME sample is a result of project workshop activity organized by four partner institutions. This fact has determined the four focus groups, while production sector was preferred.

After an introduction by the researchers about Industry 4.0 and related concepts, the participants took part to some brainstorming sessions (followed by some discussion sessions) in which they were asked to reflect on (and write on post-its) several topics related to Industry 4.0 implementation, including the main barriers and

TABLE 2

FOCUS GROUPS

\begin{tabular}{llllll} 
Key Facts & Total & Italy & Austria & Thailand & USA \\
\hline Participating SMEs & 37 & $10(27 \%)$ & $7(19 \%)$ & $10(27 \%)$ & $10(27 \%)$ \\
\hline Participants & 67 & $13(19 \%)$ & $13(19 \%)$ & $25(38 \%)$ & $16(24 \%)$ \\
\hline
\end{tabular}


difficulties faced. The data emerged from the four focus groups were then independently coded by two researchers among the authors team.

\section{RESULTS}

The focus groups allowed us to highlight several barriers for Industry 4.0 implementation in SMEs. We classified them into the same six categories used for the barriers highlighted by Industry 4.0 literature: economicfinancial, cultural, competencies/resources, technical, legal, and implementation process (see Table 3). A few barriers identified by previous literature have not emerged during the focus groups. However, several barriers/obstacles not highlighted by previous literature were highlighted by our case studies (see Table 3 ).

Majority of SMEs (from all focus groups) pointed out the high costs and uncertain return on investment of Industry 4.0 (economic-financial category), also due to the unclear market potential of Industry 4.0 and the long implementation process. Among the cultural barriers, we found the corporate culture/mentality in Italy, Austria and Thailand (in particular the lack of cooperation among functions/departments), the employee resistance in all four focus groups (due to their poor knowledge of Industry 4.0 and their fear to lose their work), the missing top management vision on Industry 4.0, and their risk aversion in Austria and Thailand. As far as the competencies/resources are concerned, SMEs from all four focus groups point out that they their managers and employees lack qualification and training on Industry 4.0. Another important issue concerns the capital/investments required.

SMEs in Italy, Thailand and USA point out that they have different ICT systems and their data are stored in different silos that do not communicate each other. Furthermore, they argue that their buildings are not designed for automating the internal transports. These technical issues make the implementation of Industry 4.0 more difficult. SMEs of some countries (e.g., Thailand and Italy) highlight some restrictions due to local laws and regulations. Finally, SMEs in Italy, Thailand and USA point out the absence of a toolset for the introduction of Industry 4.0 (implementation process category). Several differences can also be observed comparing the four analyzed countries (see Table 3 ).

\section{CONCLUSIONS}

Our paper is to the best of our knowledge among the first ones to shed empirical light on the main barriers for Industry 4.0 implementation in SMEs. This way we open a debate on a topic that is expected to rise significantly in the next few years. Our findings also have significant implications for mangers and policy-makers.

The results of our study should be viewed in light of two major limitations. First, we adopted a focus group research methodology. Despite several actions were performed to enhance validity and reliability of our findings, statistical generalization to a broader population is not allowed. Second, our sample consisted of 37 SMEs from four countries (Italy, Austria, Thailand and USA). Caution is therefore needed to extend our results to other contexts. Future research could empirically test our findings on a wider and more heterogenous sample.

\section{ACKNOWLEDGMENT}

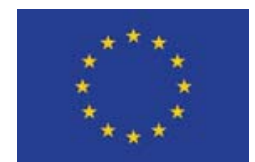

This project has received funding from the European Union's Horizon 2020 research and innovation program under the Marie Skłodowska-Curie grant agreement No 734713.

\section{REFERENCES}

[1] Organization for Economic Co-operation and Development (OECD), "Enabling the next production revolution: the future of manufacturing and services - Interim report", 2016.

[2] M. Rüßmann, M. Lorenz, P. Gerbert, M. Waldner, J. Justus, P. Engel and M. Harnisch, "Industry 4.0: The Future of Productivity and Growth in Manufacturing Industries", Boston Consulting Group, 2015

[3] Y. Liao, F. Deschamps, E. D. F. R. Loures and L. F. P. Ramos, "Past, present and future of Industry 4.0-a systematic literature review and research agenda proposal", International Journal of Production Research, vol. 55 no. 12, pp. 3609-3629, 2017.

[4] H. Kagermann, J. Helbig, A. Hellinger and W. Wahlster, "Recommendations for implementing the strategic initiative INDUSTRIE 4.0: Securing the future of German manufacturing industry", final report of the Industrie 4.0 Working Group. Forschungsunion, 2013.

[5] J. Holmström, M. Holweg, S. H. Khajavi and J. Partanen, "The direct digital manufacturing (r)evolution: definition of a research agenda", Operations Management Research, vol. 9 no. 1, pp. 1-10, 2016.

[6] V. Koch, S. Kuge, R. Geissbauer and S. Schrauf, "Industry 4.0: Opportunities and challenges of the industrial internet", Strategy \& $P w C, 2014$.

[7] J. Jäger, O. Schöllhammer, M. Lickefett and T. Bauernhansl, "Advanced complexity management strategic recommendations of handling the "Industrie 4.0" complexity for small and medium enterprises", Procedia CIRP, vol. 57, pp. 116-121, 2016.

[8] H. Kagermann, W. Wahlster and J. Helbig (2013), "Umsetzungsempfehlungen für das Zukunftsprojekt Industrie 4.0", Abschlussbericht des Arbeitskreises Industrie, Vol. 4, No. 5, 2015.

[9] A. Meißner, R. Glass, C. Gebauer, S. Stürmer and J. Metternich, "Hindernisse der Industrie 4.0-Umdenken notwendig?", ZWF Zeitschrift für wirtschaftlichen Fabrikbetrieb, vol. 112 no. 9, pp. 607-611. (2017).

[10] J. M. Müller, O. Buliga, and K. I. Voigt, "Fortune favors the prepared: How SMEs approach business model innovations in Industry 4.0", Technological Forecasting and Social Change, 2018.

[11] J. M. Müller, L. Maier, J. Veile, and K. I. Voigt, "Cooperation strategies among SMEs for implementing industry 4.0." in proceedings of the Hamburg International Conference of Logistics (HICL), pp. 301-318, 2017. 
TABLE 3

BARRIERS IN INDUSTRY 4.0 IMPLEMENTATION

\begin{tabular}{|c|c|c|c|c|c|c|}
\hline & Barriers & \begin{tabular}{|l|l}
$\begin{array}{l}\text { Highlighted } \\
\text { in literature }\end{array}$ \\
\end{tabular} & Italy & Austria & Thailand & USA \\
\hline & & & High investments with uncertain ROI & & & High tool costs and time investments \\
\hline 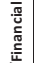 & High investements required & $\mathrm{x}$ & $\begin{array}{l}\text { High cost and high effort } \\
\text { From what size of company an investment makes } \\
\text { sense? }\end{array}$ & $\begin{array}{c}\text { Investment (machineries, Construction measures, } \\
\text {,..) }\end{array}$ & $\begin{array}{l}\text { Investment in Production System and Human training } \\
\text { (capital and time) }\end{array}$ & \\
\hline 竞 & $\begin{array}{l}\text { Lack of monetary } \\
\text { ressources }\end{array}$ & $\mathrm{x}$ & & & $\begin{array}{c}\text { Capital } \\
\text { Need a capital support } \\
\end{array}$ & Capital to invest \\
\hline 总 & $\begin{array}{l}\text { Lack of clearly defined } \\
\text { economic benefit }\end{array}$ & $\mathrm{x}$ & $\begin{array}{l}\text { Measurement of results is difficult } \\
\text { High investments with uncertain ROI }\end{array}$ & Investments/amortization & Do we recognize the impact on our company? & \\
\hline & $\begin{array}{l}\text { Product characteristics } \\
\end{array}$ & & & & Value of the product (low value is not worth) & \\
\hline 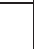 & $\begin{array}{c}\text { Lack of trust between } \\
\text { partners }\end{array}$ & $\mathrm{x}$ & Lack of intersectoral cooperation/exchange & & & \\
\hline & & & Clear direction in the company is necessary & Top Management support & Top Management has not awareness in Industry 4.0 & \\
\hline & & & Commitment of the management is important & $\begin{array}{c}\text { Mostly an unclearly defined part of the corporate } \\
\text { strategy }\end{array}$ & Mindset overview > process, plan, customer ... & \\
\hline & & & Courage for new things & & & \\
\hline & & & Lack of total vision of industry 4.0 for logistics & & & \\
\hline & Preferred autonomy & $\mathrm{x}$ & & & & $\begin{array}{c}\text { Lack of easy "best practice sharing with other } \\
\text { companies" }\end{array}$ \\
\hline & & & Lack of willingness to take risks & & & "The way we've always done it" \\
\hline & Restrictive mindset & & $\begin{array}{l}\text { People must "want" to introduce } 14.0 \text { instead of } \\
\text { being forced }\end{array}$ & & & $\begin{array}{l}\text { Changing way of thinking to modern methods of } \\
\text { thinking }\end{array}$ \\
\hline $\begin{array}{c}\mathrm{g} \\
\mathrm{\Xi}\end{array}$ & Unsupportive organizational & & & & HQ's decision-making management system & \\
\hline$\frac{2}{3}$ & \begin{tabular}{|c|} 
structure \\
\end{tabular} & & & & Complexity of the organization & \\
\hline ב & & & Acceptance of employees & Acceptance of new technologies & Attitude of a worker to accept and change & Company culture due to fear of automation \\
\hline & & & Communication to employees & Integration of employees & & \\
\hline & Acceptance or emproyees & & Employees are not yet aware of the changes & No/missing acceptance (open rejection) & & \\
\hline & & & Employees afraid of losing jobs due to new tech. & & & \\
\hline & $\begin{array}{l}\text { Lack of Support from } \\
\text { Customer/supplier }\end{array}$ & & & & Customers who are ready to support new systems & $\begin{array}{l}\text { Squeezed in the middle of supply chain, not seen } \\
\text { as strategic partner }\end{array}$ \\
\hline & & & & & Don't know the true needs of customers or the market & \\
\hline & Focus on day to day & & & & & No time to sit back and strategize \\
\hline & $\begin{array}{l}\text { Awarness about the } \\
\text { potentialities of robots }\end{array}$ & & & & & $\begin{array}{l}\text { Need to believe that if I buy a robot for a job I will } \\
\text { still be able to use it when the job is done }\end{array}$ \\
\hline & $\begin{array}{l}\text { Lack of Support by the IT } \\
\text { quarter }\end{array}$ & & & & $\begin{array}{l}\text { The organization is just a production base, not a } \\
\text { "company". It relies on parent companies in marketing } \\
\text { decision. }\end{array}$ & \\
\hline & & & Lack of qualification and training of employees & Know-How & $\begin{array}{c}\text { Gap between Traditional Operators vs. New } \\
\text { Entrepreneurs } \\
\end{array}$ & Resources (people) \\
\hline & | Lack of technical knowledge & $x$ & & ICT-barriers for employees & $\begin{array}{l}\text { Lack of expertise of personnel to supporting Industry } \\
4.0 \text { and cannot use the information effectively }\end{array}$ & Training requirements \\
\hline & Complexity & $\mathrm{x}$ & Complexity of Industry 4.0 & & & \\
\hline & & $\mathrm{x}$ & $\begin{array}{l}\text { Implementation also requires major changes from } \\
\text { supplier }\end{array}$ & & & \\
\hline & High coordination effort & & $\begin{array}{l}\text { Not all suppliers are prepared } \\
\end{array}$ & & & \\
\hline 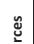 & $\begin{array}{l}\text { Need to find suitable } \\
\text { research partner }\end{array}$ & $\mathrm{x}$ & & & & \\
\hline 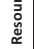 & & & $\begin{array}{c}\text { A complete overview of the market is not yet } \\
\text { available }\end{array}$ & & Solution provider & \\
\hline 产 & Lack of knowledge of & & $\begin{array}{l}\text { Missing overview of what makes sense for the } \\
\text { individual SME }\end{array}$ & & $\begin{array}{l}\text { Lack of access to the source of Information and } \\
\text { Technology }\end{array}$ & \\
\hline ( & \begin{tabular}{|l|} 
Industry 4.0 Technologies \\
and technogical providers
\end{tabular} & & & & $\begin{array}{l}\text { How SMEs access the source of technology and } \\
\text { available technology }\end{array}$ & \\
\hline ¿े & & & \begin{tabular}{|c|} 
Analysis of the need for Industry 4.0 \\
\end{tabular} & & Knowledge of the technologies & \\
\hline & & & $\begin{array}{c}\text { SMEs do not have an own "department" for industry } \\
4.0\end{array}$ & & $\begin{array}{c}\begin{array}{c}\text { Gap between Traditional Operators vs. New } \\
\text { Entrepreneurs }\end{array} \\
\end{array}$ & \\
\hline & & & Small spaces and sometimes confined conditions & & & \\
\hline & & & $\begin{array}{c}\begin{array}{c}\text { No space for automation of the logistics or internal } \\
\text { transports }\end{array} \\
\end{array}$ & & & \\
\hline & Factory layout constraints & & $\begin{array}{l}\text { Current buildings are not designed for automating } \\
\text { the internal transports }\end{array}$ & & & \\
\hline & & & $\begin{array}{l}\text { Future factory planning needs to be adapted in the } \\
\text { future }\end{array}$ & & & \\
\hline & Data security concerns & $\mathrm{x}$ & & Data security & $\begin{array}{c}\text { Data Security } \\
\end{array}$ & \\
\hline & $\begin{array}{l}\text { Lack of support by } \\
\text { government }\end{array}$ & & & & $\begin{array}{l}\text { SMEs problems are Human Resources, capital and } \\
\text { policy }\end{array}$ & \\
\hline 表 & Bureacracy & & $\begin{array}{c}\text { Bureaucracy as a hurdle for a dynamic } \\
\text { implementation of } 14.0\end{array}$ & & & \\
\hline & $\begin{array}{c}\text { Restricted laws and } \\
\text { regulations }\end{array}$ & & & Legal restrictions & Restricted laws and regulations & \\
\hline & Lack of standards & $x$ & & & & \\
\hline & $\begin{array}{l}\text { Uncertainity about the } \\
\text { reliability of the systems }\end{array}$ & $\mathrm{x}$ & $\begin{array}{l}\text { Uncertainty about the reliability of automated } \\
\text { transport or storage systems }\end{array}$ & & & \\
\hline $\bar{\sigma}$ & Weak IT infrastructure & $\mathrm{x}$ & Consistency of the IT still does not exist & Integration of existing infrastructure & & \\
\hline 农 & Storage Data & $\mathrm{x}$ & & & & \\
\hline 胥 & Difficult Interoperability/ & $\mathrm{x}$ & $\begin{array}{l}\text { Data silos without communication between each } \\
\text { other }\end{array}$ & old data --> need for adaption & Each company's system is different to be interlinked & Integration of new technology with old equipment \\
\hline & & & Missing interfaces with suppliers & Interfaces/Communication & & \\
\hline & Technology immaturity & $\mathrm{x}$ & & & & \\
\hline & State of machine park & & & & & Current state of the machine park \\
\hline & $\begin{array}{c}\begin{array}{c}\text { Need for new business } \\
\text { models }\end{array} \\
\end{array}$ & $\mathrm{x}$ & & & & \\
\hline & $\begin{array}{l}\text { Lack of methodical } \\
\text { approach for }\end{array}$ & $\mathrm{x}$ & Missing toolset for the introduction of Industry 4.0 & Few Best-Practice-Examples & What are the initial steps to improve or implement? & $\begin{array}{l}\text { There are limited support resources and a lack of } \\
\text { formalized, distilled information on how to } \\
\text { implement industry } 4.0\end{array}$ \\
\hline 氖 & implementation & & $\begin{array}{l}\text { There are no methods and approaches for the } \\
\text { correct introduction of Industry } 4.0\end{array}$ & Clear formulation of objectives vs. Solutions & $\begin{array}{l}\text { When an automatic replacement is introduced. How } \\
\text { do humans work? }\end{array}$ & \\
\hline 然 & & & Required time for implementation & Time capacities for project implementation & & High tool costs and time investments \\
\hline 吾 & Required time for & & The market and competition will not stop & & & \\
\hline . & implementation & & $\begin{array}{l}\text { Be aware that time is needed to deal with it and } \\
\text { implement industry } 4.0\end{array}$ & & & \\
\hline$\frac{\underline{\omega}}{\frac{0}{0}}$ & \begin{tabular}{|c|} 
Changes required Form \\
implementing Industry 4.0
\end{tabular} & & Adjustment of the company & & & \\
\hline & $\begin{array}{l}\text { Difficult i es Demand } \\
\text { forecasting }\end{array}$ & & & Fluctuation of order volume & Difficult in Demand forecasting & \\
\hline & & & Flexibility is the highest priority & & & Low quantity/ frequency of orders from customers \\
\hline & Product characteristics & & $\begin{array}{l}\text { Modification of the process according to changing } \\
\text { customer needs }\end{array}$ & & & \\
\hline & & & Difficult use with lot size 1 or individual products & & & \\
\hline
\end{tabular}


[12] S. Nylander, A. Wallberg, P. Hansson, "Challenges for SMEs entering the IoT world: success is about so much more than technology", in proceedings of the Seventh International Conference on the Internet of Things, Linz, Austria, p. 16. ACM. 2017.

[13] R. Otuka, D. Preston and E. Pimenidis, "The use and challenges of cloud computing services in SMEs in Nigeria", in proceedings of the European Conference on Information Management and Evaluation, vol. 43 no. 10, pp. 47-55, 2014.

[14] A. Parker and J. Tritter, "Focus group method and methodology: current practice and recent debate", International Journal of Research \& Method in Education, vol. 29 no. 1, pp. 23-37, 2006.

[15] H. S. Qiao and G. L. Wang, "An analysis of the evolution in internet of things industry based on industry life cycle theory", Advanced Materials Research, vol. 430, pp. 785789, Trans Tech Publications, 2012.

[16] C. Schröder, "The challenges of industry 4.0 for small and medium-sized enterprises". Friedrich-Ebert-Stiftung, Bonn, 2016.

[17] T. Seeberger, T. Industrie 4.0. Chancen und Herausforderungen der vierten industriellen Revolution. Munich: GRIN Verlag, 2015.

[18] M. Wenking, C. Benninghaus and T. Friedli, "Umsetzungsbarrieren und-lösungen von Industrie 4.0", ZWF Zeitschrift für wirtschaftlichen Fabrikbetrieb, vol. 111 no. 12, pp. 847-850, 2016.

[19] L. M. Zawra, H. A. Mansour, A. T. Eldin and N. W. Messiha, "Utilizing the Internet of Things (IoT) Technologies in the Implementation of Industry 4.0", International Conference on Advanced Intelligent Systems and Informatics, pp. 798-808, Springer, Cham, 2017

[20] M. Dixit, J. Kumar and R. Kumar, "Internet of things and its challenges", in Green Computing and Internet of Things (ICGCIoT), 2015 IEEE International Conference, Greater Noida,India , pp. 810-814, 2015.

[21] M. Hatler, "Industrial wireless sensor networks: Trends and developments", Retrieved, vol. 11 no. 14, 2013.

[22] S. Heng, Industry 4.0 upgrading of Germany's industrial capabilities on the horizon. Frankfurt am Main, Germany, 2014.

[23] D. O'Halloran and E. Kvochko, "Industrial internet of things: unleashing the potential of connected products and services", World Economic Forum, p. 40, 2015.

[24] Schlaepfer and Koch (2014), Industry 4.0 Challenges and solutions for the digital transformation and use of exponential technologies, Available at: https://www.i40.de/wp/wp-

content/uploads/2015/05/Deloitte-Study-Industry-40 EN Normal-Resolution.pdf.

[25] IBM, "Was kann Industrie 4.0? Und können Sie das auch?", Available at: https://www935.ibm.com/services/multimedia/Whitepaper_Industrie 4. 0 screen.pdf, 2015.

[26] P. D'Este, S. Iammarino, M. Savona and N. von Tunzelmann, "What hampers innovation? Revealed barriers versus deterring barriers", Research policy, vol. 41 no. 2 , pp. 482-488, 2012.

[27] A. Madrid $\square$ Guijarro, D. Garcia and H. Van Auken, "Barriers to innovation among Spanish manufacturing SMEs", Journal of Small Business Management, vol. 47 no. 4, pp. 465-488, 2009

[28] D. W. Stewart and P. N. Shamdasani Focus groups: theory and practice, Sage, Newbury Park, CA, 1990.
[29] A. Parker and J. Tritter, "Focus group method and methodology: current practice and recent debate", International Journal of Research \& Method in Education, vol. 29 no. 1, pp. 23-37, 2006. 